\title{
Retraction Note: The majority of conversion total hip arthroplasties can be considered a primary replacement: a matched cohort study
}

Soufiane Aharram ${ }^{1,2^{*}}$ (D) Mounir Yahyaoui ${ }^{1,2}$, Jawad Amghar ${ }^{1,2}$, Abdelkarim Daoudi $^{1,2}$ and Omar Agoumi ${ }^{1,2}$

\section{Retraction to: Eur J Med Res (2020) 25:69 https://doi.org/10.1186/s40001-020-00467-6}

The Editor-in-Chief has retracted this Article due to substantial overlap with an unpublished manuscript by Dr. Georges Vles and colleagues. In addition to this, there is substantial overlap with another article by Aharram et al. which was under consideration at the same time [1].

None of the authors have responded to any correspondence from the editor or publisher about this retraction. a matched cohort study. Journal of Orthopaedics Trauma Surgery and Related Research. Retrieved from https://www.jotsrr.org/articles/themajority-of-conversion-total-hip-arthroplasties-can-be-considered-aprimary-replacement-a-matched-cohort-study-6140.html

\section{Publisher's Note}

Springer Nature remains neutral with regard to jurisdictional claims in published maps and institutional affiliations.

\begin{abstract}
Author details
${ }^{1}$ Department of Trauma and Orthopaedics, University Mohammed Premier Oujda, Mohammed VI Oujda Morocco Hospital Center, Oujda University, BP 4806, 60049 Oujda, Morocco. ${ }^{2}$ Faculty of Medicine and Pharmacy of Oujda, Department of Traumatology Orthopeadic Surgery, CHU Mohammed VI, Oujda University, BP 4806, 60049 Oujda, Morocco.
\end{abstract}

Published online: 08 September 2021

\footnotetext{
References

1. Aharram, S., Yahyaoui, M., Amghar, J. et al. (2020) The majority of conversion total hip arthroplasties can be considered a primary replacement:
}

\footnotetext{
*Correspondence: aharram.1993@gmail.com

1 Department of Trauma and Orthopaedics, University Mohammed

Premier Oujda, Mohammed VI Oujda Morocco Hospital Center, Oujda University, BP 4806, 60049 Oujda, Morocco

Full list of author information is available at the end of the article
}



2021. Open Access This article is licensed under a Creative Commons Attribution 4.0 International License, which permits use, sharing, adaptation, distribution and reproduction in any medium or format, as long as you give appropriate credit to the original author(s) and the source, provide a link to the Creative Commons licence, and indicate if changes were made. The images or other third party material in this article are included in the article's Creative Commons licence, unless indicated otherwise in a credit line to the material. If material is not included in the article's Creative Commons licence and your intended use is not permitted by statutory regulation or exceeds the permitted use, you will need to obtain permission directly from the copyright holder. To view a copy of this licence, visit http://creativecommons.org/licenses/by/4.0/. The Creative Commons Public Domain Dedication waiver (http://creativeco mmons.org/publicdomain/zero/1.0/) applies to the data made available in this article, unless otherwise stated in a credit line to the data. 